\title{
DAMPAK IMPLEMENTASI SMM ISO 9001:2008 TERHADAP BUDAYA MUTU PADA SMK DI KABUPATEN GUNUNGKIDUL
}

\author{
Nugroho Wibowo \\ Program Studi Pendidikan Teknologi dan Kejuruan \\ bhowo_boccra@yahoo.co.id \\ Sutarto HP \\ Universritas Negeri Yogyakarta \\ sutartonur@yahoo.com
}

\begin{abstract}
Abstrak
Tujuan penelitian ini untuk mengevaluasi implementasi SMM ISO 9001:2008 dan mengetahui dampak pelaksanaannya terhadap pembentukan budaya mutu di bidang Sumber Daya Manusia $(S D M)$, pengendalian pembelajaran dan sarana prasarana di SMKN 2 Wonosari dan SMK Muhammadiyah 1 Playen.Penelitian ini merupakan penelitian evaluasi. Metode pemilihan sampel menggunakan purposive sampling. Instrumen yang dipakai meliputi wawancara, dokumentasi, observasi dan angket. Subjek penelitian untuk instrumen wawancara dan studi dokumentasi adalah pengelola SMM ISO 9001:2008 yang terdiri dari kepala sekolah, wakil kepala sekolah manajemen mutu, pengelola unit kerja SDM, kurikulum, dan sarana prasarana. Data yang digali menggunakan angket berasal dari guru, sedangkan observasi digunakan untuk mengamati keadaan yang terjadi pada implementasi dan dampak budaya mutu yang ditimbulkannya. Teknik analisa data dalam penelitian ini menggunakan teknik analisa kualitatif dan kuantitatif.Hasil penelitian menunjukkan:1) pelaksanaan SMM ISO 9001:2008 telah memenuhi persyaratan yang ditentukan; dan 2) pelaksanaan SMM ISO 9001:2008terbukti membentuk budaya mutu karena telah teridentifikasi sembilan indikator budaya mutu.
\end{abstract}

Kata kunci: SMM ISO 9001:2008, budaya mutu

\section{THE IMPACT OF THE IMPLEMENTATION OF SMM ISO 9001:2008 ON THE QUALITY CULTURE IN VOCATIONAL HIGH SCHOOLS IN GUNUNGKIDUL REGENCY}

\begin{abstract}
This study aims to evaluate the implementation of SMM ISO9001:2008and investigate the impact of the implementation in the areas of human resources, learning control, and infrastructure facilities in SMKN 2 Wonosari and SMK Muhammadiyah1 Playen.This was an evaluation study employing. The sample selection method in this study was the purposivesampling method. The data collecting techniques included interviews, documentation study, observations, and questionnaires. The subjects for the interviews and document study were the managerial personnel of SMM ISO 9001:2008, consisting of principals, vice principals in charge of the quality management, and the managerial personnel of the sections of the Human Resources, Curriculum, and Infrastructure Facilities. The data collected through questionnaires were from the teacher sample, and observations were carried out to observe the conditions related to the implementation and the impact on the resulting quality culture. The data analysis in the study was the qualitative and quantitative data analysis. The results of the study are as follows. 1) In terms of the implementation of SMM ISO9001:2008 it has fulfilled requirements; and 2)The implementation proves to have formed the quality culture because nine indicators of the quality culture can be identified.
\end{abstract}

Keywords: SMM ISO 9001:2008, quality culture 


\section{PENDAHULUAN}

Peningkatan mutu pendidikan merupakan suatu hal yang terus berkembang di era globalisasi ini, sekolah sebagai penghasil Sumber Daya Manusia (SDM) memegang peranan penting dalam proses peningkatan tersebut. Setiap sekolah dituntut untuk terus meningkatkan mutu pendidikan agar lulusannya unggul dan dapat bersaing dengan lulusan Sekolah Menengah Kejuruan (SMK) yang lain

Penjaminan mutu pendidikan di sekolah adalah proses penetapan dan pemenuhan standar mutu pengelolaan pendidikan secara konsisten dan berkelanjutan, sehingga stakeholders (siswa, orangtua, dunia kerja, pemerintah, guru, tenaga penunjang, dan pihak lain) memperoleh kepuasan (Tim Penjaminan Mutu LPMP DIY, 2012:1). Konsep utama sistem penjaminan mutu adalah adanya perencanaan yang baik, kajian internal seluruh unsur sekolah, dan manajemen pengelolaan yang berkelanjutan, ketiga hal tersebut digunakan untuk pengambilan keputusan berkaitan dengan kegiatan yang dilaksanakan oleh sekolah.

Peningkatan mutu pendidikan sudah direncanakan oleh pemerintah, dalam mengatur langkahnya pemerintah menyusun strategi dasar kebijakan pendidikan Departemen Pendidikan Nasional berisi: (1) Perluasan dan pemerataan akses pendidikan; (2) peningkatan mutu, daya saing, dan relevansi pendidikan; dan (3) penguatan tatakelola, akuntabilitas, dan citra publik pendidikan (Renstra Departemen Pendidikan Nasional, 2010:62).

Sistem Manajemen Mutu (SMM) adalah suatu sistem manajemen untuk mengarahkan dan mengendalikan suatu organisasi/institusi dalam penetapan kebijakan, sasaran, rencana dan proses/prosedur mutu serta pencapaiannya secara berkelanjutan. Salah satu SMM yang dapat diberlakukan ditingkat pendidikan adalah SMM ISO 9001:2008, sistem ini bertujuan untuk menjaga dan meningkatkan mutu sebuah organisasi, di dalamnya memuat delapan prinsip manajemen mutu yang mengacu pada prinsip fokus pada pelanggan, keterlibatan menyeluruh, kepemimpinan, pendekatan proses, pendekatan sistem ke manajemen, adanya perbaikan berkelanjutan, pengambilan keputusan berdasarkan fakta, dan hubungan dengan pemasok yang bersifat menguntungkan (Tim ISO SMK Negeri 4 Yogyakarta, 2011:3).

Proses pelaksanaan SMM ISO 9001:2008 membutuhkan proses yang panjang, dimulai dari proses persiapan, proses pembuatan dan pengesahan dokumen, proses implementasi dan proses sertifikasi (PPPPTK Bisnis dan Manajemen, 2009:18).Prosedur-prosedur yang terdapat dalam dokumen-dokumen SMM juga bersifat mengikat sehingga mutlak harus dilaksanakan dengan didukung data-data yang akurat dan bisa dipertanggungjawaban, kedua kesulitan di atas memungkinkan sekolah mengalami kesulitan dalam melaksanakan sistem ini.

Penjaminan mutu tidak berarti membuat kualitas meningkat, dan peningkatan mutu yang diinginkan hanya terjadi di beberapa bagian. Prosedur dan data-data yang tersedia cenderung hanya memberi kesan sistem berjalan, banyak data yang dibuat-buat, terlalu banyak laporan dan membutuhkan banyak perhatian. However, this does not mean that quality work and quality improvement are integrated parts of the sector. Available evidence rather suggests that while systems, procedures and rules are being laid down, creating much data, many reports and much attention (Harvey \& Stansaker, 2008:1).

Penyusunan program peningkatan mutu dapat dilakukan dengan mengaplikasikan empat teknik, (Umiarso \& Imam Gojali, 2010:147-150) yaitu: (1) school review, (2) benchmarking, (3) quality assurance, dan (4) quality control. SMM ISO 9001:208 bertujuan untuk menentukan bahwa proses pendidikan telah berlangsung sebagaimana seharusnya, dengan teknik ini dapat dideteksi adanya penyimpangan yang terjadi pada proses (Eddy Sutadji:30). Kandungan didalamnya merupakan prosedur-prosedur yang disusun untuk pelaksanaan kegiatan disekolah, akhir yang diharapkan adalah meningkatnya mutu sekolah yang didalamnya terkandung budaya mutu disemua aspek pendidikan.

Budaya kualitas adalah sistem nilai organisasi yang menghasilkan suatu lingkungan yang kondusif bagi pembentukan dan perbaikan kualitas secara terus menerus. Budaya kualitas terdiri dari filosofi, keyakinan, sikap norma, 
nilai, tradisi, prosedur, harapan yang meningkatkan kualitas (Tjiptono \& Diana,1998:75). Transformasi menuju sekolah bermutu terpadu diawali dengan mengadopsi dedikasi bersama terhadap mutu oleh dewan sekolah, administrator, staf, siswa, guru dan komunitas (Arcaro, 2007:10). Bila semua warga sekolah memahami dan menginternalisasi konsep dan sekaligus mengaplikasikan budaya mutu dalam segala aktifitas dalam proses pendidikan di lingkungan sekolah, maka akan menghasilkan mutu lulusan yang unggul dan kerkualitas.

Pembentukan budaya bertujuan untuk mencari tujuan akhir yang diinginkan, Deal \& Peterson (1999:19) menyatakan konsep budaya membantu kita memahami berbagai pola budaya yang ada, memahami harapan atau tujuan, dan bagaimana pengaruh budaya itu.

"The concept of culture helps us understand these varied petterns-understand what they are. How they come to be, and how they affect performance". Peningkatan mutu tidak hanya tergantung pada aspek-aspek utama seperti SDM, sarana prasarana atau kurikulum tetapi juga aspek-aspek non teknis seperti pembentukan kultur atau budaya mutu.

Townsend (1994:15) menggambarkan bahwa sekolah harus menciptakan output berupa budaya sekolah yang baik sebagai langkah untuk menjadi sekolah yang efektif, lebih lanjut dijelaskan sekolah efektif adalah sekolah yang tidak hanya berorentasi pada tujuan pencapaian pendidikan, tetapi pada keberhasilan proses pembelajaran dan mencintai belajar, pengembangan personal dan rasa percaya diri, keterampilan hidup, memecahkan masalah, mengembangkan kebebasan berfikir dan rasa percaya diri dan semua yang berhubungan dengan outcome sekolah efektif seperti sukses dalam disiplin akademik.

Kabupaten Gunungkidul terdapat lima SMK Negeri dan tiga SMK swasta yang sudah menerapkan SMM ISO 9001:2008 dari total 41 SMK yang ada, yaitu SMKN 1 Wonosari, SMKN 2 Wonosari, SMKN 3 Wonosari, SMKN 1 Saptosari, SMKN 1 Ngawen, SMK YAPPI Wonosari, SMK Muh. 1 Wonosari, dan SMK Muh. 1 Playen. Data terakhir menunjukkan bahwa peringkat hasil Ujian Nasional (UN) dua tahun terakhir se-Kabupaten Gunungkidul belum seluruhnya menunjukan bahwa implementasi SMM ISO 9001:2008 menghasilkan dampak yang baik dari segi hasil proses pembelajaran di sekolah dilihat dari segi hasil UN.

Dari uraian di atas dapat ditarik kesimpulan bahwa salah satu usaha peningkatan mutu pendidikan disekolah adalah diterapkannya SMM ISO 9001:2008, implementasi sistem tersebut diharapkan dapat meningkatkan mutu sekolah. Salah satu indikator sekolah yang mempunyai mutu yang baik ditandai dengan tumbuhnya budaya mutu. Budaya mutu sekolah yang baik pada akhirnya akan membuat sekolah mempunyai kultur yang membuat sekolah selalu berkembang untuk mengantisipasi kebutuhan di era globalisasi.

\section{Sistem Manajemen Mutu (SMM) ISO 9001:2008}

Secara garis besar SMM ISO 9001:2008 adalah standar internasional tentang sistem manajemen mutu yang berfokus pada pelanggan dan selama proses pelaksanaanya dengan menggunakan persyaratan-persyaratan standar yang sudah ditetapkan untuk membantu organisasi menetapkan dan menggembangkan demi memenuhi kepuasan pelanggan (customer statisfaction) dan peningkatan mutu terus-menerus (continuous processes improvement).

Dalam pelaksanaan SMM ISO 9001:2008 sebuah organisasi harus menetapkan, mendokumentasikan, menerapkan dan memelihara sistem manajemen mutu dan terus-menerus memperbaiki keefektifannya sesuai dengan persyaratan. Kewajiban yang harus dilaksanakan oleh sebuah organisasi adalah:(1) menentukan proses yang diperlukan untuk sistem manajemen mutu dan penerapannnya di seluruh organisasi; (2) menetapkan urutan dan interaksi proses-proses ini; (3) menetapkan kriteria dan metode yang diperlukan untuk memastikan bahwa baik operasi maupun kendali proses-proses ini efektif; (4) memastikan tersedianya sumberdaya dan informasi yang diperlukan untuk mendukung operasi dan pemantauan proses-proses tersebut; (5) memantau, mengukur dan menganalisa proses-proses ini; dan (6) menerapkan tindakan yang diperlukan untuk mencapai hasil yang direncanakan dan perbaikan berlanjut (http://iso.org, 2009:2). 


\section{Implementasi SMM ISO 9001:2008}

Tahap implementasi merupakan pelaksanaan dari semua yang telah ditulis didalam dokumen (Usman, 2006:447). Tahap ini merupakan proses dilaksanakan prosedur-prosedur yang telah dibuat, prosedur yang telah dilaksanakan harus selalu terdokumentasi dengan baik, dokumen tersebut disebut sebagai rekaman. Rekaman diperlukan untuk menganalisis segala yang berkaitan dengan pelaksanaan SMM, karena sistem manajemen ini selalu menggunakan data dan fakta dalam proses menjalankannya.

Semua kegiatan yang dilakukan harus terdokumentasi, mereka menggunakan skema siklus Plan/Do/Check/Adjust sebagai model proses Total Quality Management (TQM) (Tjiptono \&Diana, 1998:348).

Beberapa langkah penting dalam mengimplementasikan manajemen mutu (Sallis, 2011:244-253) adalah: (1) kepemimpinan dan komitmen terhadap mutu; (2) mengembirakan pelanggan; (3) menunjuk fasilitator mutu; (4) membentuk kelompok pengendali mutu; (5) menunjuk koordinator mutu; (6) mengadakan seminar manajemen senior untuk mengevaluasi program; (7) menganalisa dan mendiagnosa situasi yang ada; (8) menggunakan contohcontoh yang sudah berkembang ditempat lain; (9) mempekerjakan konsultan eksternal; (10) memprakarsai pelatihan mutu bagi staf; (11) mengkomunikasikan pesan mutu; (12) mengukur biaya mutu; dan (13) mengaplikasikan alat dan teknik mutu melalui pengembangan kelompok kerja yang efektif.

\section{Implementasi bidang SDM}

Personel yang melaksanakan pekerjaan yang mempengaruhi kesesuaian persyaratan produk harus berkemampuan berdasarkan pendidikan, pelatihan, ketrampilan dan pengalaman yang sesuai. Dalam persyaratan SMM ISO, organisasi harus: (1) menetapkan kemampuan yang diperlukan bagi personel yang melaksanakan pekerjaan yang mempengaruhi kesesuaian persyaratan produk; (2) jika diperlukan, menyediakan pelatihan atau melakukan tindakan lain untuk mencapai kompetensi yang sesuai; (3) menilai keefektifan tindakan yang dilakukan; (4) memastikan bahwa personelnya sadar akan pentingnya kegiatan mereka dan kontribusi mereka terhadap pencapaian sasaran mutu; dan (5) memelihara rekaman yang sesuai dari pendidikan, pelatihan, ketrampilan dan pengalaman (http://iso.org, 2009:7)

\section{Implementasi bidang Pengendalian Pembelajaran}

Organisasi harus merencanakan dan melaksanakan produksi dan penyediaan jasa dalam keadaan terkendali: (1) tersedianya informasi yang menguraikan karakteristik produk; (2) tersedianya instruksi kerja secukupnya; (3) pemakaian peralatan yang sesuai; (4) tersedianya dan pemakaian sarana pemantauan dan pengukuran; (5) penerapan pemantauan dan pengukuran; dan (6) penerapan kegiatankegiatan pelepasan produk, pengiriman dan pasca penyerahan.(http://iso.org, 2009:12)

\section{Implementasi bidang Sarana Prasarana}

Organisasi harus menetapkan, menyediakan dan memelihara prasarana yang diperlukan untuk mencapai kesesuian persyaratan produk. (http://iso.org, 2009;7).

\section{Budaya Mutu}

Budaya Mutu dapat diartikan sebagai budaya kualitas, budaya kualitas menurut Goetsch \& Davis (Tjiptono \& Diana,1998:75) adalah sistem nilai organisasi yang mendasari organisasi yang menghasilkan suatu lingkungan yang kondusif bagi pembentukan dan perbaikan kualitas secara terus menerus. Budaya kualitas terdiri dari filosofi, keyakinan, sikap, nilai, tradisi, prosedur, dan harapan yang meningkatkan kualitas.

Budaya mutu dalam penelitian ini adalah nilai, moral, sikap dan perilaku seluruh komponen sekolah yaitu pemerintah, siswa, guru, staf tata usaha, dan lingkungan masyarakat disekitarnya yang sudah disepakati, dengan unsur-unsur yang terkandung didalamnya meliputi: (1) Perilaku sesuai dengan slogan (visi, misi dan motto sekolah); (2) susunan manajemen/struktur pembagian tugas yang jelas dan sesuai dengan kewenangan; (3) informasi dari pelanggan digunakan untuk perbaikan atau peningkatan mutu; (4) karyawan dilibatkan dan diberdayakan; (5) fokus pada proses dan terdapat aturan-aturan untuk proses pelaksa- 
naan serta ada tindakan perbaikan; (6) hubungan dan komunikasi yang bersinergi antara sekolah, pelanggan, pemasok untuk peningkatan mutu; (7) sumber daya yang profesional dengan penghargaan dan pembelajaran; (8) berorientasi pada output mutu yang dihasilkan; (9) kepedulian dan tanggungjawab dari seluruh anggota sekolah.

\section{METODE PENELITIAN}

\section{Jenis penelitian}

Penelitian ini merupakan penelitian evaluasi (evaluation research) dengan pendekatan campuran yang bertujuan untuk mengevaluasi program pelaksanaan SMM ISO 9001:2008 dan dampak yang ditimbulkannya yaitu pembentukan budaya mutu.Model evaluasi yang dilakukan dengan model logic, komponenkomponen yang dievaluasi adalah komponen masukan (inputs), proses (activities), hasil (outputs), dan dampak (outcome).

\section{Waktu dan Tempat penelitian}

Waktu penelitian dilaksanakan pada bulan Maret sampai dengan Juni 2013. Tempat penelitian di SMKN 2 Wonosari dan SMK Muhammadiyah 1 Playen.

\section{Subjek Penelitian}

Populasi dalam penelitian ini adalah pengelola SMM ISO 9001:2008. Metode pemilihan sampel menggunakan metode purposive sampling, teknik penentuan sampel dengan pertimbangan dari segi besarnya keterlibatan dalam mengimplementasikan SMM ISO 9001:2008. Jumlah sampel yang digunakan: untuk wawancara sejumlah 4 orang Wakil Kepala Sekolah dan 5 orang pengelola SMM ISO 9001:2008. Untuk instrumen angket di SMKN 2 Wonosari mengambil sampel sejumlah 60 guru, sedangkan di SMK Muhammadiyah 1 Playen berjumlah 30 guru.

\section{Prosedur}

Data penelitian digali menggunakan 4 instrumen yaitu wawancara, studi dokumentasi, observasi dan angket. Untuk memenuhi validitas isi, instrumen terlebih dahulu disusun berdasarkan kisi-kisi instrumen yang selanjutnya dimintakan pendapat dari para ahli (judgement expert) untuk mengukur apakah item instrumen telah mencakup keseluruhan isi obyek yang diukur. Untuk memenuhi keabsahan data kualitatif digunakan triangulasi data, baik triangulasi teknik dan sumber.

\section{Data, Instrumen dan Teknik Penggumpulan Data}

Komponen input menggunakan instrumen studi dokumentasi dan wawancara, komponen proses menggunakan observasi, wawancara dan angket, komponen produk menggunakan instrumen dokumentasi dan wawancara, sedangkan komponen dampak menggunakan instrumen observasi, wawancara dan angket.

\section{Teknik Analisis Data}

Teknik analisa data yang digunakan menggunakan teknik analisa kualitatif dan kuantitatif, data kualitatif dari hasil observasi, wawancara, dan dokumentasi dianalisis untuk mempertajam penilaian dalam menarik kesimpulan. Proses analisis data kualitatif menggunakan model interatif, dimana terdapat empat tahap yaitu: data collection, reduction, display, and conclusion. (Miles and Huberman, 1994:76). Analisis data kuantitatif pada angket menggunakan teknik analisa deskriptif dengan persentase yaitu membandingkan skor yang dicapai dengan skor maksimum, dan selanjutnya diinterpretasikan sesuai dengan kriteria.

\section{HASIL PENELITIAN DAN PEMBAHASAN}

\section{SMK N 2 Wonosari Gunungkidul}

\section{Implementasi SMM ISO 9001:2008}

Implementasi bidang SDM

Komponen input telah mendukung implementasi SMM ISO 9001:2008 bidang SDM karena pengelola telah mempunyai pengalaman berkaitan dengan ketugasannya. Sarana prasarana pendukung tersedia dengan baik dari segi jumlah maupun kualitas dan tersedia akses yang mudah dalam pengelolaan SDM. Dokumen UK SDM tersedia dan telah memenuhi prosedur yang ditetapkan dan tersedia tempat khusus untuk meletakkannya. 
Persyaratan yang pertama dilakukan dengan penetapan kriteria-kriteria perangkat sekolah yang diatur dalam IK yang ada di UK SDM, kriteria yang diatur antara lain kriteria Kepala Sekolah, WMM, Waka I, Waka II, Waka III, Waka IV, Kaprodi, Wali Kelas, Guru, BP/BK, Ka TU, Petugas Perpustakaan, Urusan Kepegawaian, Urusan Kesiswaan, Urusan Keuangan, Tool man, Satpam, Pesuruh, dan Petugas MR. Hal di atas menunjukkan bahwa sekolah telah melaksanakan persyaratan pertama pada klausul 62, walaupun dalam pelaksanaanya masih ditemukan masalah yaitu sering tidak samanya antara kebutuhan SDM dengan penerimaan SDM yang diberikan ke sekolah karena pengelolaan berada pada Pemerintah Daerah.

Persyaratan yang kedua tentang peningkatan kompetensi SDM ditemukan data peningkatan kompetensi dilakukan melalui: (a) Diklat intern yaitu diklat yang dilakukan sekolah secara mandiri, pesertanya adalah seluruh personil sekolah; (b) Diklat Ekstern yaitu sekolah mengirimkan usulan permohonan diklat kepada lembaga diklat dan mengirimkan peserta diklat apabila terdapat undangan diklat.

Upaya peningkatan kompetensi bagi SDM dilakukan sekolah dengan menyediakan pelatihan untuk peningkatan kompetensi SDM dan melakukan upaya yang lain yaitu pengusulan dan pengiriman peserta diklat ke lembaga terkait, sehingga telah memenuhi persyaratan yang kedua di klausul 6.2. Penilaian keefektifan kegiatan UK dilakukan melalui evaluasi sasaran mutu setiap tahun, untuk kegiatan diklat efektifitas dikelola melalui kewajiban membuat laporan bagi peserta diklat dan evaluasi dampak diklat yang dilakukan oleh Ka Unit Kerja SDM, persyaratan yang ketiga telah terpenuhi di SMK N 2 Wonosari.

Upaya sadar dari personil sekolah dilakukan dengan peningkatan kompetensi secara mandiri yaitu beberapa personil sekolah melakukan usaha peningkatan kompetensi menggunakan dana secara mandiri dengan cara kelanjutan sekolah S2, seminar, workshop dan mengikuti perlombaan. Persyaratan yang terakhir yaitu pendokumentasian dokumen-dokumen kepegawaian, dokumen laporan diklat dan evaluasinya terdokumentasi dengan baik di UK SDM.
Beberapa guru telah mengikuti lomba dan ada yang sudah berprestasi yaitu mendapatkan penghargaan Guru Teladan tingkat Kabupaten tahun 2011, selain itu terdapat tiga orang guru PNS yang mempunyai jabatan guru sebagai Guru Pembina Tk.I/IVb.Hal di atas menunjukkan pengelolaan SDM telah diatur oleh sekolah dan menghasilkan prestasi.

Dari data angket dapat disimpulkan bahwa guru merasa sekolah telah menetapkan kompetensi yang dibutuhkan untuk bekerja di lembaga ini sudah tersusun dengan baik terbukti dari prosentase sebesar $82,45 \%$ dari skor maksimal. Indikator yang kedua yaitu pelaksanaan diklat diperoleh skor terkecil yaitu $70,04 \%$ dari skor maksimal yang mengindikasikan bahwa pelaksanaan diklat dirasa belum memuaskan guru. Secara keseluruhan untuk implementasi SMM ISO 9001:2008 bidang SDM diperoleh skor $76,52 \%$ yang tergolong dalam kategori tinggi.

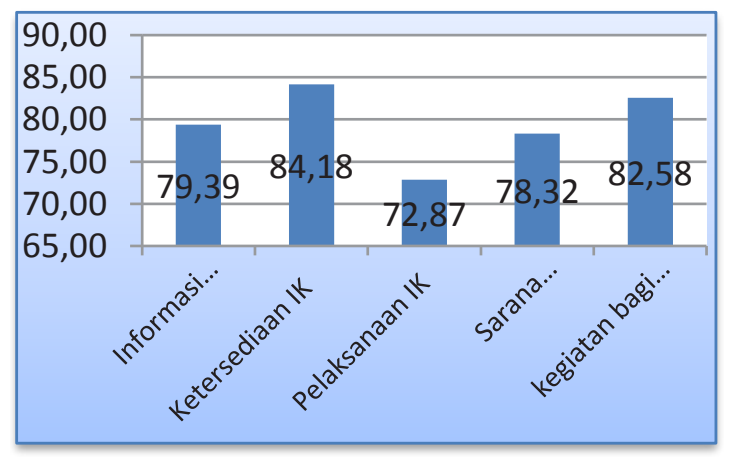

Gambar 1. Data Angket bidang SDM

\section{Implementasi bidang Pengendalian Pembela- jaran}

Komponen input yaitu pengelola, sarana prasarana pendukung dan dokumen SMM ISO telah memenuhi kebutuhan dan mempermudah dalam proses pengelolaan pembelajaran.

Informasi karakteristik lulusan dapat dilihat pada kurikulum yang diterapkan di SMK N 2 Wonosari yaitu KTSP, sekolah telah menambahkan beberapa indikator yang dirasa penting untuk upaya peningkatan lulusan. Penambahan indikator tersebut dilakukan oleh tim pengembang kurikulum yang beranggotakan KS, Waka Kurikulum dan staf, KMGMP serta Kaprodi.

Instruksi Kerja pengendalian pembelajaran terdiri dari 10 IK yang terbagi menjadi tiga hal, yaitu: perencanaan, pelaksanaan, dan 
pemantauan. Proses perencanaan dilakukan melalui penyusunan buku administrasi guru sebagai persiapan pembelajaran, proses yang kedua adalah pelaksanaan pengendalian pembelajaran, pengendalian pembelajaran dilakukan oleh guru mata pelajaran bersama dengan guru piket.

Proses pemantauan dilakukan oleh KS, Waka SDM dan Sarpras dan Tim Waka Kurikulum, KS berkeliling di lingkungan sekolah setiap hari dengan waktu yang tidak menentu, sedangkan untuk Waka SDM berkeliling sekolah selama tiga kali sehari. Pemantauan dari tim Waka Kurikulum dilakukan dengan cara pemantuan pembelajaran rutin yang dilakukan oleh tim dengan berkoordinasi dengan KMGMP dan Kaprodi, pemantauan yang kedua dilakukan dengan pertemuan rutin dua bulanan bersama ketua kelas, materi pertemuanya adalah masukan dari kelas tentang pembelajaran yang telah berlangsung.

Persyaratan yang terakhir adalah adanya kegiatan yang dilakukan bagi lulusan, kegiatan siswa setelah melakukan UN adalah bimbingan sekolah lanjutan bagi yang ingin melanjutkan ke Perguruan Tinggi dari BP/BK, proses sertifikasi tes TOEIC, dan proses rekruitmen tenaga kerja dari industri.

Output mutu yang dihasilkan oleh SMKN 2 Wonosari dapat dilihat dari nilai $\mathrm{UN}$, secara posisi masih berada pada rangking ke 3 ditahun 2010/2011 dan rangking ke 3 ditahun 2011/2012. Berbagai kejuaraan diraih oleh siswa-siswi di sekolah ini pada tahun 2012 yang terdiri dari 13 kejuaraan di tingkat Kabupaten, 9 buah di tingkat propinsi dan 1 kejuaraan ditingkat Nasional. Jumlah lulusan SMK N 2 Wonosari yang dapat disalurkan bekerja melalui BKK Sekolah untuk tahun 2011/2012 sebanyak 200 siswa dari total 420 lulusan atau sekitar 47,61\%. Hal di atas menunjukkan bahwa terdapat prestasi yang ditunjukkan oleh siswa sebagai hasil dari proses pembelajaran yang dilakukan di SMKN 2 Wonosari.

Data angket dengan responden guru, indikator pelaksanaan IK memperoleh skor terendah yaitu $72,87 \%$ yang menerangkan bahwa masih terdapat masalah dalam proses pelaksanaan IK, yaitu tentang pemahaman prosedurprosedur yang ada, langkah yang dilakukan untuk menanggulanginya dengan pemahaman ulang lewat pertemuan rutin di sekolah. Skor tertinggi yaitu $84,18 \%$ diperoleh indikator yang ketersediaan IK, hal ini menunjukkan guru merasa semua aturan yang berhubungan dengan pengendalian pembelajaran telah tersedia. Secara keseluruhan untuk pelaksanaan implementasi di bidang pengendalian pembelajaran diperoleh skor $79,47 \%$ dari skor maksimal yang termasuk dalam kategori tinggi.

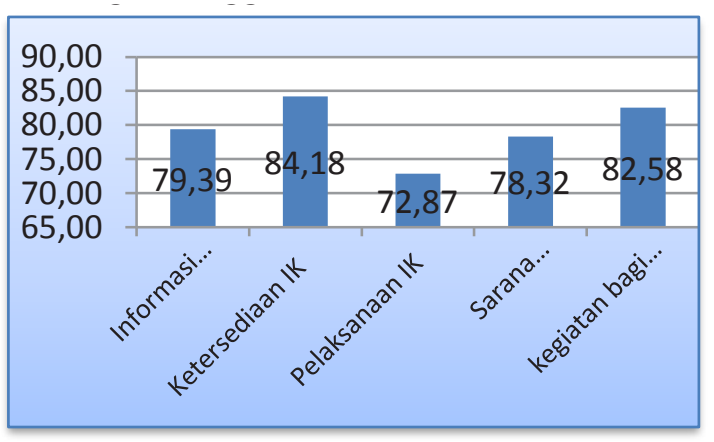

Gambar 2. Implementasi bidang Pembelajaran

\section{Implementasi bidang Sarana Prasarana}

Pengelola UK sarpras mempunyai pengalaman selama 12 tahun mengelola sarpras dengan berbagai diklat berkaitan dengan pengelolaan sarpras. Sarana pendukung berupa ruang UK dan perlengkapannya sangat mendukung dalam proses pengelolaan sarpras.

Tiga hal yang diatur dalam pengelolaan Sarpras dan sarana penunjang di SMM ISO 9001:2008 meliputi sekolah menetapkan, mengadakan dan memelihara sarana dan prasarana. Proses dimulai dari usulan kebutuhan, usulan kebutuhan dilakukan Ka Unit Kerja program keahlian dan KTU, semua personil sekolah berhak untuk mengusulkan dengan menulis formulir kebutuhan yang ada di UK. Proses yang kedua dilakukan pembahasan untuk diverifikasi, proses ini adalah mengidentifikasi kebutuhan yang memang harus dilakukan pembelian karena kebutuhan yang mendesak, dan kebutuhan rutin yang harus dibeli. Proses ini juga untuk memilah penggunaan dana yang digunakan, dana dapat dialokasikan melalui dana APBD Propinsi atau dana Komite Sekolah.Hasil dari pembahasan dimasukan dalam RKAS, proses selanjutnya adalah proses pembelian, proses ini dilakukan oleh Tim Belanja Sekolah yang penunjukkannya sudah diatur 
dengan IK/62/Waka I/34, tim belanja sekolah beranggotakan tim Waka Sarpras dan personil dari jurusan.

Pengelolaan sarana prasarana digudang dikelola oleh Petugas Pemegang Barang yang dibantu oleh Petugas Pembantu Pemegang Barang.Proses pemeliharaan atau Maintenance and Repairing (MR) dilakukan dengan membagi ruang lingkup MR menjadi dua, yang pertama adalah lingkup sarpras umum dan sarpras yang berada dijurusan. Pemeliharaan sarpras umum dilakukan oleh tim Waka I yaitu staf RT-LH sedangkan sarpras yang berada di Prodi dikelola oleh Prodi masing-masing. Proses MR dijurusan dilakukan oleh toolman dibantu oleh guru dan siswa dibawah koordinasi Kepala Bengkel. Masalah yang dihadapi dalam proses MR adalah tidak tercukupinya dana untuk pemeliharaan selama satu tahun karena data yang ada sekitar 5 juta rupiah pertahun.

Output pengelolaan sarpras dilihat dari keluhan pelanggan, selama ini belum pernah terjadi keluhan pelanggan yang mengakibatkan proses pembelajaran terganggu, sehingga dapat disimpulkan bahwa dari segi output yaitu pengelolaan sarpras telah terlaksana dengan baik.

Data angket menunjukkan bahwa guru merasa penyediaan sarpras masih belum maksimal dilihat dari skor yang diperoleh yaitu $67,91 \%$, sedangkan indikator yang ketiga yaitu sekolah menetapkan mendapat skor tertinggi yaitu $71,10 \%$ yang menunjukkan bahwa proses penerapan sudah sesuai dengan aturan yang ditetapkan. Secara keseluruhan diperoleh skor rata-rata $69,86 \%$ dari skor maksimal dan termasuk dalam kategori tinggi.

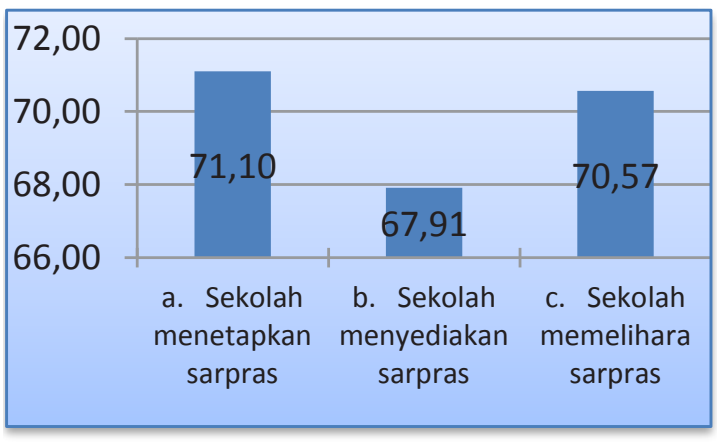

Gambar 3. Implementasi bidang sarpras

\section{Dampak Implementasi SMM ISO 9001:2008 terhadap Pembentukan Budaya Mutu}

Indikator pertama dari budaya dalam penelitian ini adalah perilaku sesuai dengan slogan, terdapat slogan-slogan yang bertujuan untuk menginspirasi dan memotivasi SDM. Slogan terpampang di seluruh lingkungan sekolah. Terdapat peningkatan pengaruh slogan terhadap perilaku SDM setiap tahunnya, sekolah mengelola slogan-slogan tersebut dengan manambah dan memperbaruinya setiap tahun dan menganggarkannya dalam RAPBS.

Indikator kedua yaitu adanya struktur organisasi dan uraian tugas yang jelas, indikator tersebut sudah diatur di IK sesuai dengan UK masing-masing. Setiap UK terdapat struktur organisasi dan uraian tugas yang jelas untuk mengatur personil dalam proses pelaksanaan kegiatan. Manfaat yang dirasakan adalah lebih mudah dalam melakukan pekerjaan dan mempermudah Ka Unit Kerja dalam proses pemantauan.

Indikator selanjutnya adalah informasi dari pelanggan yang digunakan untuk perbaikan, informasi didapatkan melalui hasil kuisioner pelanggan, komunikasi langsung dengan personil UK SDM, lewat telpon, SMS maupun surat yang ditujukan ke sekolah. Proses tindak lanjut dari informasi tersebut dilakukan melalui dua kriteria, kriteria pertama yang bersifat kebijakan maka harus menunggu keputusan sekolah setelah adanya rapat manajemen sekolah. Kriteria yang kedua yang bersifat penanganan suatu masalah maka sesegera mungkin diselesaikan oleh sekolah dengan bekerjasama dengan unit kerja terkait.

Keterlibatan warga sekolah diidentifikasi dalam kepanitiaan kegiatan sekolah, rata-rata guru atau karyawan pernah menjadi panitia kegiatan minimal satu kali dalam setahun, keterlibatan yang kedua berbentuk usulan perbaikan untuk SMM ISO 9001:2008, walaupun belum semua warga sekolah memberikan usul perbaikan. Keterlibatan yang lain adalah keterlibatan berupa dukungan warga sekolah ketika perlombaan yang diikuti siswa, keterlibatan selanjutnya adalah keterlibatan warga sekolah terhadap kegiatan sosial. 
Proses pengelolaan SDM, pengendalian pembelajaran dan sarpras telah memuat aturanaturan yang jelas dan sudah ditetapkan menjadi sebuah Prosedur Operasional Standar (POS) dan diimplementasikan dalam bentuk IK, sehingga memudahkan pengelola untuk melaksanakan kegiatan.

Hubungan dan komunikasi yang bersinergi antara sekolah, pelanggan, pemasok untuk peningkatan mutu merupakan indikator selanjutnya, komunikasi tersebut dilakukan dengan pelanggan menggunakan angket kuisioner pelanggan, pelanggan yang mengisi angket yaitu siswa, wali murid dan industri.

Pemberian reward untuk guru yang berprestasi dilakukan dengan dasar guru yang telah mencapai sasaran mutu yang telah ditentukan, reward tersebut berupa surat keterangan dan hadiah berupa voucher belanja dikoperasi sekolah. Pemberian hadiah kepada siswa diberikan kepada siswa yang mendapatkan nilai 10 pada mata pelajaran UN, peringkat $1-10$ rata-rata UN dan memenangkan suatu perlombaan tertentu berupa surat keterangan dan gratis iuran bulanan selama kurun waktu tertentu. Sedangkan bentuk pembinaan oleh sekolah kepada SDM yang mengalami masalah melalui hirarki pembinaan lewat teguran lisan dari Waka SDM, kemudian dipanggil secara tertulis untuk dilakukan pembinaan oleh Waka SDM bersama dengan KTU dan KS, proses pembinaan diatur dalam IK/62/Waka I/22.

Orientasi mutu output terlihat pada sasaran mutu di UK setiap tahunnya, analisis sasaran mutu menggunakan data-data tahun sebelumnya dan unsur-unsur penunjang dan penghambat sekolah. Sasaran mutu di setiap UK memacu setiap warga sekolah untuk dapat mencapainya sehingga segala bentuk kegiatan diupayakan untuk mendukung ketercapaian sasaran mutu.

Bentuk-bentuk kepedulian dan rasa tanggung jawab personil di SMKN 2 Wonosari dapat diidentifikasi dari kepedulian untuk peningkatan mutu sekolah dengan kelanjutan studi S2, mencari solusi ketika ditemukan terdapat kelas yang kosong. Kepedulian yang lain ditunjukkan oleh warga sekolah dengan kepedulian bentuk waktu dan materi ketika membimbing lomba, pembimbing memanfaatkan waktu lebih dari waktu yang tersedia, kepedulian juga ditunjukkan oleh warga sekolah terhadap siswa yang mempunyai potensi putus sekolah melalui pengumpulan dana lewat beasiswa rapus.

Dari data angket disimpulkan bahwa guru merasa sekolah belum maksimal dalam proses pemberdayaan warga sekolah dengan prosentase rata-rata $71,06 \%$ dari skor maksimum. Indikator perilaku sesuai dengan slogan mempunyai prosentase rata-rata tertinggi dengan $81,70 \%$ menunjukkan perilaku yang dilakukan warga sekolah telah menunjukkan sesuai dengan slogan yang ada disekolah. Secara keseluruhan untuk angket budaya mutu diperoleh skor $76,10 \%$ yang termasuk dalam kategori tinggi.

\section{SMK Muhammadiyah 1 Playen}

\section{Implementasi SMM ISO 9001:2008}

\section{Implementasi bidang SDM}

Data komponen input menunjukkan telah mendukung pelaksanaan SMM ISO 9001:2008 dengan catatan bahwa ruang UK terlalu sempit sehingga penggunaan dan penataan ruang terkesan semrawut. Pengalaman diklat berkaitan dengan SDM perlu diadakan karena diklat dapat mendukung kompetensi pengelola untuk mengelola lebih baik.

Pelaksanaan kelima persyaratan dalam klausul 6.2 telah terpenuhi dengan data dan permasalahan sebagai berikut:

a) Penetapan kompetensi yang dibutuhkan telah dilakukan dengan penetapan kriteria sesuai dengan aturan di IK/6.2/Waka I/4 dan IK/6.2/Waka I/5 tentang persyaratan tenaga pendidik dan syarat menduduki jabatan tertentu. Permasalahan yang muncul terdapat tiga orang guru yang tidak sesuai dengan persyaratan S1, tetapi mereka berkomitmen menyelesaikan pendidikan.

b) Sekolah mengadakan diklat bagi seluruh guru yang dilaksanakan setiap tahun yang dinamakan workshop awal tahun, selain itu pengembangan yang lain dilakukan dengan pengajuan dan pengiriman peserta diklat ke lembaga diklat, pengikutsertaan guru melalui MGMP dan pengembangan kompetensi keahlian melalui In House Training (IHT) yang mengundang nara 
sumber dari instansi lain serta melalui kunjungan studi banding ke sekolah yang dianggap mempunyai prestasi.

c) Penilaian keefektifan dari proses pengembangan kompetensi dilakukan melalui laporan oleh peserta diklat, evaluasi kedua melalui tindak lanjut dari diklat yang dilaksanakan.

d) Peningkatan kompetensi ditunjukan para guru dengan mengikuti program-program pengembangan kompetensi yang ditunjuk oleh sekolah seperti kegiatan seminar, workshop, studi banding, dan kegiatan MGMP.

e) Pengelolaan dokumen dilakukan mulai dari pengelolaan laporan diklat, sertifikat, dan materi diklat tersimpan secara pada file masing-masing guru, data tersimpan di ruang Tata Usaha.

Hasil angket guru menunjukkan pelaksanaan bidang SDM memperoleh skor rerata $79,82 \%$ dari skor maksimum dan termasuk kategori tinggi.Dari data angket menunjukkan bahwa guru merasa penetapan kompetensi belum dilaksanakan dengan baik dengan perolehan skor $75,00 \%$ dari skor maksimal, perolehan tersebut merupakan perolehan terkecil dari lima indikator yang ada.

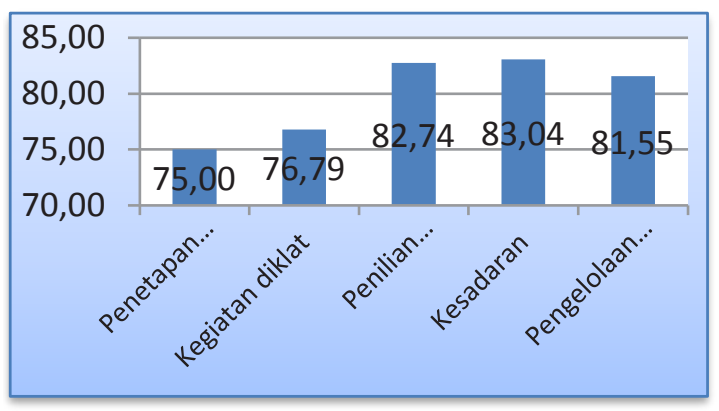

Gambar 4. Implementasi bidang SDM

\section{Implementasi bidang Pengendalian Pembela- jaran}

Komponen input telah mendukung pelaksanaan SMM ISO 9001:2008 terbukti dengan latar belakang pengelola yang berijazah S1 dan sedang menempuh S2 dan beberapa kali mengikuti diklat berkaitan dengan kurikulum. Dokumen pelaksanaan pengendalian pembelajaran telah tersedia di ruang UK, sarana pendukung pelaksanaan tersedia walaupun dari segi kualitas masih kurang yang teridentifikasi dari luas ruangan yang terlalu sempit dan tidak adanya ruang guru piket di kampus II

Persyaratan yang harus dilakukan dalam rangka implementasipengendalian pembelajaran adalah:

a) Tersedianya informasi yang menguraikan karakteristik lulusan

Informasi tersebut disampaikan kepada warga sekolah melalui kurikulum yang dilaksanakan, yaitu kurikulum KTSP. Tahapan pelaksanaannya: pertama, analisis struktur kurikulum yang ada di KTSP selanjutnya yang kedua penyusunan silabus dan yang terakhir adalah penyusunan Rencana Pelaksanaan Pembelajaran (RPP) dan administrasi pendukungnya.

b) Tersedianya IK secukupnya Instruksi Kerja yang meliputi empat bagian yaitu:(1)Perencanaan; (2) Pelaksanaan;(3) Pelaksanaan Evaluasi pembelajaran dan tindak lanjutnya; dan (4) Proses administrasi hasil pembelajaran.

c) Pemakaian peralatan yang sesuai Pelaksanaan IK yang ada di UK Kurikulum berjalan lancar walaupun terdapat beberapa permasalahan tentang pemahaman IK yang tidak sama antar warga sekolah. Data angket menyebutkan bahwa pelaksanaan IK memperoleh skor terkecil yaitu $78,57 \%$ dari skor maksimal. Permasalahan tersebut di atas diantisipasi sekolah melalui pemahaman ulang (awareness) pada rapat rutin yang dilaksanakan setiap hari senin dan setiap tanggal 20 setiap bulannya ketika penerimaan honorarium.

d) Tersedianya sarana pemantauan, pengukuran dan penerapannya.

Syarat ke empat dan kelima ini di SMK Muhammadiyah I Playen telah dilakukan dengan teridentifikasi pemantauan pengendalian pembelajaran. Hal tersebut dilakukan melalui guru piket yang memantau proses pembelajaran berlangsung, KS memantau pembelajaran dengan berkeliling setiap hari yang waktunya tidak tentu. Data angket menunjukkan bahwa paraguru merasa proses pemantauan dan pengukuran yang dilaksanakan sekolah telah dapat mengelola proses pembelajaran den- 
gan baik sehingga tidak terjadi masalah dengan pembelajaran, hal ini sesuai dengan data diperoleh skor $85,27 \%$ dari skor maksimal.

e) Penerapan kegiatan-kegiatan bagi lulusan. Persyaratan yang terakhir dalam klausul pengendalian pembelajaran yaitu aktifitas kegiatan bagi lulusan dilakukan dengan pelaksanaan Kunjungan Industri (KI), pengenalan sekolah lanjutan bagi yang ingin melanjutkan dan kegiatan rekruitmen tenaga kerja melalui BKK.

Output mutu yang dihasilkan dari pelaksanaan pembelajaran yang telah berlangsung adalah hasil nilai $\mathrm{UN}$, data menunjukkan bahwa terdapat penurunan nilai di UN dua tahun terakhir, walaupun untuk tingkat Kabupaten terjadi penurunan nilai rata-rata di dua UN terakhir. Hasil kejuaraan lomba olahraga menunjukkan bahwa SMK Muhammadiyah 1 Playen dapat merebut 11 mata perlombaan di perlombaan olahraga tingkat Kabupaten. Data dari sekolah menunjukkan untuk tahun pelajaran 2011/2012 lulusan yang bekerja melalui BKK berjumlah 190 dari 426 lulusan atau jika diprosentase sebesar 44,60\%.

Data angket menyebutkan bahwa secara keseluruhan skor pelaksanaan bidang pengendalian pembelajaran adalah $82,81 \%$ dari skor maksimum dan termasuk kategori tinggi.

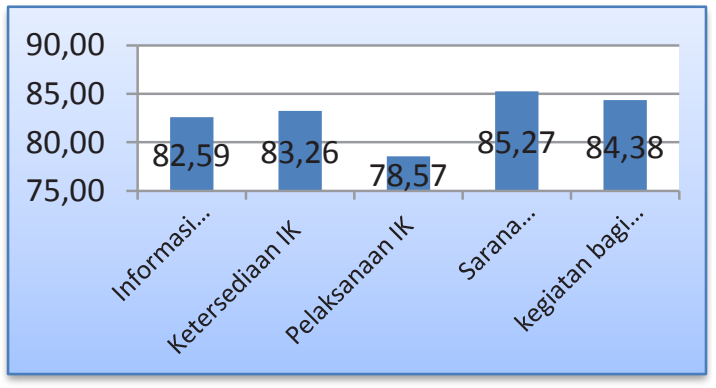

Gambar 5. Implementasi bidang pengendalian pembelajaran

\section{Implementasi bidang Sarpras}

Data studi dokumentasi menunjukkan terdapat dokumen-dokumen pengelolaan sarpras: data inventaris alat, data inventaris perabot, data usulan alat, data penggunaan alat, dan data
MR. Dari segi latar belakang pendidikan dan pengalaman diklat berkaitan dengan pengelolaan barang pernah dilakukan oleh sehingga dapat mendukung implementasi bidang sarpras. Ruang UK mempunyai akses dengan ruang TU sehingga dapat mempermudah komunikasi walaupun dari segi luas terlalu sempit.

Tiga hal yang diatur dalam pengelolaan sarpras (klausul 63) meliputi sekolah menetapkan, mengadakan dan memelihara sarana dan prasarana. Proses penetapan sarana prasarana yang yang digunakan oleh seluruh warga sekolah dilakukan oleh urusan RT berdasarkan usulan dari warga sekolah, sedangkan sarpras yang digunakan di program keahlian dilakukan oleh program keahlian. Usulan penetapan kemudian oleh Waka Sarpras dikonsultasikan ke bendahara berkaitan dengan ketersediaan dana, setelah dana tersedia maka kemudian dikonsultasikan lagi ke KS, jika KS sudah menyetujui maka proses pengadaan dilakukan oleh tim belanja sekolah, dan terakhir didistribusikan ke UK. Data angket menyebutkan bahwa indikator penetapan memperoleh skor tertinggi yaitu $82,14 \%$ yang menunjukkan bahwa warga sekolah telah menerima proses penetapan yang dilakukan oleh sekolah.

Proses pemeliharaan atau Maintenance and Repairing (MR) sarpras umum dilakukan oleh Waka Sarpras bersama dengan urusan RT, sedangkan sarpras yang ada di program keahlian proses MR dilakukan oleh program. Data angket guru diperoleh data bahwa pemeliharaan sarpras dirasakan kurang dibanding dengan dua indikator lainnya yaitu penetapan dan pengadaan, skor yang diperoleh yaitu 77,38\% dari skor maksimal. Data yang lain adalah data dari instrumen angket, secara keseluruhan dari data angket diperoleh skor $80,26 \%$ dari skor maksimum dan termasuk kategori tinggi.

Output pengelolaan sarpras adalah meningkatnya kualitas dan kuantitas sarpras yang ada disekolah, hal ini telah dirasakan oleh warga sekolah dengan indikasi bahwa warga merasa sejak diimplementasikan SMM ISO 9001:2008 telah terjadi peningkatan kualitas dan kuantitas sarpras. 


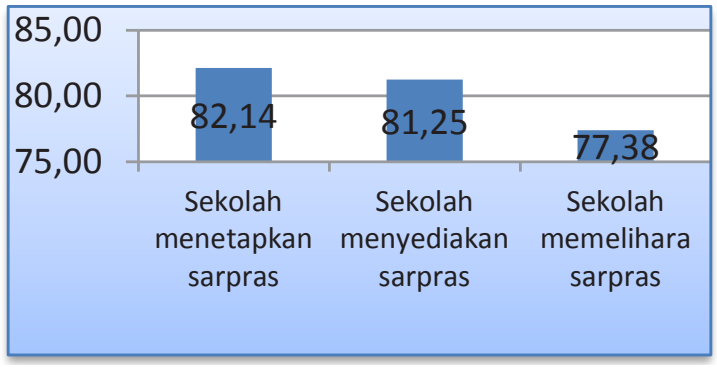

Gambar 6. Implementasi bidang sarpras

\section{Dampak Implementasi SMM ISO 9001:2008 terhadap Pembentukan Budaya Mutu}

Secara keseluruhan dari angket guru diperoleh data bahwa skor rata-rata menunjukkan $82,16 \%$ dari skor maksimum dan termasuk kategori tinggi.

Indikator pertama yaitu perilaku sesuai dengan slogan, tema slogan bersifat informasi visi dan misi sekolah, kebijakan mutu dan usaha meningkatkan motivasi untuk belajar dan beribadah.Perkembangan perilaku SDM mengalami perkembangan yang signifikan sejak dipasangnya slogan, dengan kata lain terdapat pengaruh pemasangan slogan terhadap perilaku SDM.

Indikator kedua yaitu adanya struktur organisasi dan uraian tugas yang jelas, indikator tersebut sudah diatur di IK sesuai dengan UK masing-masing. Setiap UK terdapat struktur organisasi dan uraian tugas yang jelas untuk mengatur personil dalam proses pelaksanaan kegiatan.

Indikator selanjutnya adalah informasi dari pelanggan yang digunakan untuk perbaikan, selama ini informasi didapatkan melalui hasil kuisioner pelanggan setiap unit kerja, komunikasi langsung dari siswa ke personil sekolah dan komunikasi dengan personil sekolah ketika pembagian raport. Proses tindak lanjut dari informasi pelanggan dianalisis oleh $\mathrm{Ka}$ Unit Kerja, apabila dirasa mendesak maka diadakan rapat manajemen sekolah untuk menindaklanjuti masalah yang ada, sedangkan jika masalah itu dianggap tidak mendesak maka diagendakan untuk dilaksanakan ditahun ajaran yang akan datang.

Keterlibatan warga sekolah dapat diidentifikasi dalam kepanitiaan kegiatan sekolah, keterlibatan menyeluruh dari warga sekolah yang tinggi ditunjukkan warga sekolah melalui ke- giatan yang berhubungan dengan Penerimaan Peserta Didik Baru (PPDB) dan pembimbingan Lomba Keterampilan Siswa (LKS). Keterlibatan yang lain adalah keterlibatan warga sekolah terhadap kegiatan sosial.

Proses pengelolaan SDM, pengendalian pembelajaran dan sarpras telah memuat aturan-aturan yang jelas dan sudah ditetapkan menjadi sebuah Prosedur Operasional Standar (POS) dan diimplementasikan dalam bentuk IK, sehingga memudahkan pengelola untuk melaksanakan kegiatan.

Informasi dari pelanggan sebagai wujud dari komunikasi antar sekolah dengan pelanggan digali dari kuisioner yang dikelola oleh masing-masing UK, dari data yang terkumpul di UK kemudian direkapitulasi oleh UK selanjutnya dilaporkan ke WMM. Komunikasi selanjutnya dilakukan melalui penyampaian langsung oleh siswa kepada personil UK, komunikasi juga dilakukan melalui penyampaian langsung kepada sekolah ketika ada acara yang berhubungan dengan wali murid.

Pemberian reward untuk guru yang berprestasi di ranah kurikulum belum dilakukan secara rutin, baru dilakukan sebatas ucapan motivasi ketika diadakan rapat, pemberian uang transport bagi guru yang hadir sebelum pukul 07.00 WIB dan pulang setelah pukul 13.30 WIB senilai sepuluh ribu rupiah setiap kehadiran yang diberikan setiap bulan dan transport kehadiran mengikuti upacara bendera setiap hari senin. Bentuk punishment dilakukan melalui pembinaan rutin setiap hari senin sehabis upacara, sedangkan pembinaan SDM yang bermasalah dilakukan melalui pemanggilan kepada personil yang bersangkutan dan apabila tidak ada perubahan maka dilanjutkan pemanggilan oleh KS.

Orientasi mutu sebagai acuan sekolah dalam pelaksanaan kegiatan sekolah, terlihat bahwa sekolah mempunyai sasaran mutu pada setiap tahun ajaran. Sasaran mutu menunjukkan bahwa terdapat orientasi mutu yang akan dituju oleh SMK Muhammadiyah 1 Playen, sasaran mutu sekolah merupakan hal yang dirasakan warga sekolah dapat memotivasi warga sekolah dalam aktivitas kegiatan disekolah untuk peningkatan mutu sekolah, hal ini terbukti dengan perolehan skor pada data angket sebesar $84,82 \%$ dari skor maksimal. 
Kepedulian dan rasa tanggung jawab guru terhadap usaha peningkatan mutu sekolah terlihat pada sisi proses pembelajaran, guru-guru berusaha untuk mencari solusi jika tidak terjadi proses pembelajaran yaitu dengan mengkomunikasikan antara kelas dengan guru pengampu mata pelajaran atau guru piket. Bentuk kepedulian yang lain bentuknya seperti pembimbingan persiapan lomba melebihi dari anggaran yang ditentukan sekolah. Kepedulian dan tanggung jawab di bidang MR sarpras umum dirasakan memang kurang dari personil warga sekolah, seperti ditunjukkan pada data angket budaya mutu dengan skor $80,54 \%$ dari skor maksimal yang merupakan skor terkecil dari sembilan indikator budaya mutu dalam penelitian ini.

\section{SIMPULAN DAN SARAN}

1. Berdasarkan analisis data dalam penelitian ini implementasi SMM ISO 9001:2008 dari segi inputs, activities dan outputs di SMKN 2 Wonosari dapat disimpulkan:

a. Implementasi dibidang SDM telah memenuhi lima persyaratan yang ditentukan, dan berdasar data angket diperoleh skor rata-rata $76,52 \%$ dari skor maksimum dan termasuk dalam kategori tinggi.

b. Bidang pengendalian pembelajaran telah memenuhi enam persyaratan yang diatur, dan berdasar data angket diperoleh skor rata-rata $79,46 \%$ dari skor maksimum dan dalam kategori tinggi.

c. Bidang sarana prasarana telah melalui tiga persyaratan yang ditentukan dan berdasar data angket diperoleh skor rata-rata $69,85 \%$ dari skor maksimum dan dalam kategori tinggi.

2. Implementasi SMM ISO 9001:2008 dari segi inputs, activities dan outputs di SMK Muhammadiyah 1 Playen dapat disimpulkan:

a. Dalam bidang SDM telah memenuhi lima persyaratan yang dipersyaratkan, dan dari data angket diperoleh skor rata-rata $79,82 \%$ dari skor maksimum dan termasuk kategori tinggi. b. Bidang pengendalian pembelajaran telah memenuhi enam persyaratan yang ditentukan, dan dari data angket diperoleh skor rata-rata $82,81 \%$ dari skor maksimum dan termasuk kategori tinggi.

c. Bidang sarana prasarana telah melalui tiga persyaratan yang ditentukan dan dari data angket diperoleh skor ratarata $80,26 \%$ dari skor maksimum dan termasuk kategori tinggi.

3. Dalam proses implementasi SMM ISO 9001:2008 di SMKN 2 Wonosari berdampak pada pembentukan budaya mutu karena telah teridentifikasi sembilan faktor budaya mutu pada penelitian ini, dan dari data angket diperoleh skor rata-rata $76,10 \%$ dari skor maksimum dan dalam kategori tinggi.

4. Dalam proses implementasi SMM ISO 9001:2008 di SMK uhammadiyah 1 Playen berdampak pada pembentukan budaya mutu karena telah teridentifikasi sembilan faktor budaya mutu pada penelitian ini, dan dari data angket diperoleh skor ratarata $82,16 \%$ dari skor maksimum dan termasuk dalam kategori tinggi.

Berdasarkan kesimpulan di atas, maka disampaikan beberapa saran yaitu:

1. SMKN 2 Wonosari Gunungkidul:

a. Dalam implementasi bidang SDM diperlukan peningkatan pengelolaan diklat baik diklat intern maupun ekstern dalam upaya peningkatan kompetensi SDM.

b. Diperlukan penyediaan sarana prasarana yang mencukupi baik dari segi kualitas maupun kuantitas sesuai dengan kebutuhan diindustri.

c. Perlu peningkatan pemberdayaan warga sekolah terutama untuk peningkatan mutu agar warga sekolah merasa memiliki sekolah yang pada akhirnya dapat meningkatkan motivasi dan kinerja.

2 SMK Muhammadiyah 1 Playen:

a. Diperlukan konsistensi dan evaluasi terus menerus pada pelaksanaan implementasi SMM ISO 9001:2008 
terutama bidang SDM dan pengendalian pembelajaran.

b. Perlunya diadakan kegiatan-kegiatan yang dapat meningkatkan kepedulian warga sekolah dalam upaya peningkatan mutu sekolah.

c. Diperlukan upaya-upaya tindakan pencegahan agar pelaksanaan MR di sarpras umum dapat berjalan dengan baik karena pengelolaan sarpras dapat mempengaruhi berjalannya kegiatan pembelajaran disekolah.

\section{DAFTAR PUSTAKA}

Arcaro,.J.S. (2007). Quality in Education: An Implemention Handbook. San Francisco:St. Lucie Press.

Deal, T. E.,\& Peterson, Kent. D.(1999). Shaping School Culture :The Heart of Leadership. San Fransisco: Jose Bass Publishers.

Depdiknas.(2004). Renstra Departemen Pendidikan Nasional 2010-2014. Jakarta: Direktorat Pendidikan Menengah Umum.

Eddy Sutadji. (2009). Model Evaluasi Mutu Sekolah, Pengembangan Instrumen untuk Menetapkan Mutu. Desertasi doktor. tidak diterbitkan, Universitas Negeri Yogyakarta, Yogyakarta.

Harvey, L., \& Stansaker, B. (2008). Quality Culture:Understanding, Boundaries and Linkage.Europen Journal of Education, Vol. 43, No 4.
Miles, M.B., \& Huberman, A.M. (1994). Qualitatif Data Analysis: An Expended Sourcebook. London: Sange Publication.

PPPPTK Bisnis dan Manajemen. (2009, Oktober). Menuju Sekolah ISO 9001:2000. Makalah disampaikan pada pelatihan SMM ISO 9001:2000, di PPPPTK Bisnis dan Manajemen .

Sallis, E. (2011). Total Quality Management in Education. Yogyakarta: IRCiSoD

The Ultimate SME Implementation Guide for ISO 9001:2008 ISO 14001:2004 Management System. Section 2 ISO 9001:2008 version 2005. (Versi elektronik). Diambil pada tanggal 27 Februari 2009, dari http://iso.org.

Tjiptono, F \& Anastasia, A.(1998) Total Quality Management(TQM). Yogyakarta: Penerbit Andi.

Townsend, T. (1994). Effective Schooling for the Community. Core Plus Education. London: Routledge.

Tim Penjaminan Mutu LPMP DIY. (2012, Oktober). Sistem Manajemen Mutu. Makalah disampaikan pada Pendampingan Sekolah Model Penjaminan Mutu Pendidikan, di LPMP DIY.

Usman, H. (2006). Manajemen. Teori, Praktik, Riset Pendidikan. Jakarta: Bumi Aksara.

Umiarso \& Imam Gojali (2010), Manajemen Mutu Sekolah di Era Otonomi Pendidikan.Yogyakarta: IRCiSoD. 